\title{
Anna Moï, Espéranto, désespéranto. La francophonie sans les Français
}

Ilaria Vitali

\section{(2) OpenEdition}

\section{Edizione digitale}

URL: https://journals.openedition.org/studifrancesi/46332

DOI: 10.4000/studifrancesi.46332

ISSN: 2421-5856

\section{Editore}

Rosenberg \& Sellier

\section{Edizione cartacea}

Data di pubblicazione: 1 octobre 2007

Paginazione: 480

ISSN: 0039-2944

\section{Notizia bibliografica digitale}

Ilaria Vitali, «Anna Moï, Espéranto, désespéranto. La francophonie sans les Français», Studi Francesi

[Online], 152 (LI | II) | 2007, online dal 30 novembre 2015, consultato il 24 novembre 2021. URL: http:// journals.openedition.org/studifrancesi/46332 ; DOI: https://doi.org/10.4000/studifrancesi.46332

Questo documento è stato generato automaticamente il 24 novembre 2021.

\section{(c) (i) (9)}

Studi Francesi è distribuita con Licenza Creative Commons Attribuzione - Non commerciale - Non opere derivate 4.0 Internazionale. 


\title{
Anna Moï, Espéranto, désespéranto. La francophonie sans les Français
}

\author{
Ilaria Vitali
}

\section{NOTIZIA}

ANNA MOÏ, Espéranto, désespéranto. La francophonie sans les Français, Paris, Gallimard, 2006, pp. 67.

1 «Être écrivaine me suffirait; mais je suis aussi écrivaine francophone. Comme Marcel Proust et Boualem Sansal» (p. 53). Potrebbe essere il manifesto di questo bellissimo saggio, in cui l'autrice vietnamita Anna Moï racconta, in termini poetici, in che modo sia entrata a far parte della cittadella della francofonia, che considera, da molti punti di vista, come un «club cloisonné».

2 Espéranto, désespéranto è strutturato in tre parti, ognuna delle quali affronta, in modo diverso, le molteplici sfaccettature del rapporto tra lingua e creazione artistica. La prima, «Écriture et langue», è una sorta di manifesto poetico, in cui l'autrice racconta come sia arrivata alla scrittura e alla scelta del francese, dopo aver imparato sei lingue diverse. La seconda parte, «Écriture et confucianisme», traccia il percorso che l'ha progressivamente allontanata dalla lingua vietnamita, in cui si sentiva «captive et inégale» (p. 41), appartenendo a una minoranza etnica definita con il termine moï, «selvaggio». Oggi, quel nome è diventato lo pseudonimo letterario che l'ha resa, stando alle sue parole, doppiamente libera, quasi eretica: «An signifie "tranquillité". - spiega l'autrice - Nam, "sud"; annam-moï, "tranquillité-sud-sauvage"; anna moï: "anna sauvage"» (p. 44).

3 La terza e ultima parte del saggio, «Écriture et francophonie», è infine dedicata al rapporto dell'autrice con lo strumento espressivo del quale ha scelto di servirsi: la lingua francese. In questa sezione, Anna Moï spiega come la francofonia sia un concetto «esclusivo», unico al mondo, che non trova corrispettivi nel mondo anglosassone. Non mancano, in questa parte, le note polemiche nei confronti di chi preferisce 
«etichettare» gli autori invece di leggerli, capirne le problematiche messe in campo e apprezzarne la presa di distanza dalle regole imposte dall'uso della lingua. Al contrario, secondo l'autrice, lo scrittore, come ogni artista, è libero di scegliere il proprio materiale di lavoro e ha il dovere di oltrepassare le frontiere senza timore. «Étrangers et écrivains, on transgressera les frontières sans outrecuidance, on emmêlera les pinceaux - voire, le pinceau et la plume - sans étre soupçonné d'iconoclastie. On pourra malaxturer des mots et, toujours nonchalindolent, revendiquer l'innocence» (p. 26).

4 Un saggio in forma di racconto poetico, scritto in una lingua cesellata, raffinata e precisa, capace di trasportare il lettore nell'officina letteraria dell'autrice. 